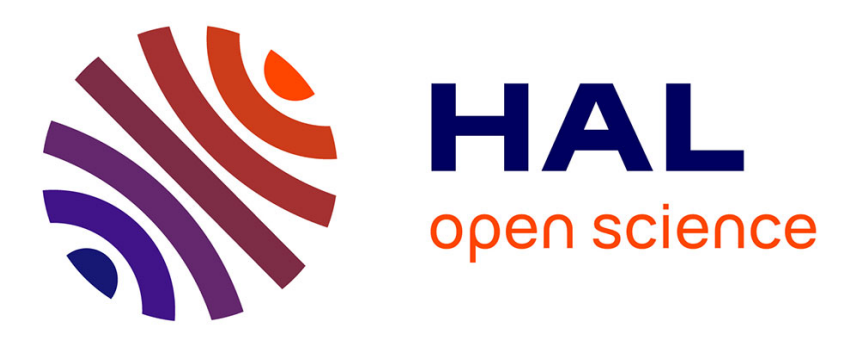

\title{
Population densities and deforestation in the Brazilian Amazon: New insights on the current human settlement patterns
}

Isabelle Tritsch, François-Michel Le Tourneau

\section{- To cite this version:}

Isabelle Tritsch, François-Michel Le Tourneau. Population densities and deforestation in the Brazilian Amazon: New insights on the current human settlement patterns. Applied Geography, 2016, 76, pp.163 - 172. 10.1016/j.apgeog.2016.09.022 . hal-01425695

\section{HAL Id: hal-01425695 \\ https://hal.science/hal-01425695}

Submitted on 3 Jan 2017

HAL is a multi-disciplinary open access archive for the deposit and dissemination of scientific research documents, whether they are published or not. The documents may come from teaching and research institutions in France or abroad, or from public or private research centers.
L'archive ouverte pluridisciplinaire HAL, est destinée au dépôt et à la diffusion de documents scientifiques de niveau recherche, publiés ou non, émanant des établissements d'enseignement et de recherche français ou étrangers, des laboratoires publics ou privés. 


\section{Population densities and deforestation in the Brazilian Amazon: New insights on the current human settlement patterns}

- Isabelle Tritsch ${ }^{*}$,

- François-Michel Le Tourneau

- Centre de Recherche et de Documentations sur les Amériques (CREDA), UMR 7227, Centre National de la Recherche Scientifique (CNRS), University Sorbonne Nouvelle, 28 Rue Saint-Guillaume, 75007 Paris, France

Received 7 December 2015, Revised 6 September 2016, Accepted 17 September 2016, Available online 28 September 2016 http://www.sciencedirect.com/science/article/pii/S0143622816304568

http://dx.doi.org/10.1016/i.apgeog.2016.09.022

\section{Highlights}

- Low overall relations between population density and deforestation.

- One third of Amazon deforestation is associated with only $1.5 \%$ of the population.

- In contrast, $13 \%$ of the rural population live in preserved forests.

- 'Discrete urbanization' of rural areas: multiplication of small towns.

\section{Abstract}

This paper provides the first analysis at the sub-municipality scale of the relationships between population densities and deforestation in the Brazilian Amazon between 2000 and 2010. We use the database on deforestation published by the Brazilian space research center (INPE) and the population census data released by the federal geographical and statistical agency IBGE at their finest scale: the census tract level. By crossing the population density and deforestation variables, we identify ten human settlement patterns in the Amazon. There are low-low and high-high classes of population density and deforestation, but also low-high and high-low classes. This analysis helps understand the low overall relations in the Amazon for population and deforestation. We emphasize the expansion of large-scale agriculture and cattle ranching as causing the depopulation of rural areas while in many regions of the Amazon quite strong population densities coexist with relatively low extents of deforestation. Such findings stress the need to implement case-specific public policies in these regions in order to encourage human presence compatible with the conservation of forest cover and biodiversity. We also confirm the importance of the Amazon urbanization process, including the 'discrete urbanization' of rural areas, and the need to better recognize the distinct social and environmental problems of urban areas.

\section{Keywords}


- Human settlement patterns;

- Deforestation;

- Population density;

- Urbanization;

- Spatial analysis;

- Brazilian Amazon

\section{Introduction}

The impact of population settlement on natural resources has been a central issue in population and environmental studies. In the tropical forests, a number of case studies have shown a positive relation between population density and deforestation (Ehrhardt-Martinez, 1998, Laurance et al., 2014 and López-Carr and Burgdorfer, 2013). However, since the 2000s, this paradigm has been changing, and human population density is no longer pointed out as the principal determinant of tropical deforestation in land-use change studies. Instead, it is viewed as a factor interacting with complex social, economic, and political processes at local and global levels (DeFries et al., 2010, Geist and Lambin, 2002, Pacheco et al., 2011 and Rudel et al., 2009).

For the Brazilian Amazon, which represents $40 \%$ of the world's remaining tropical rainforests (FAO, 2011) and supplies important ecosystem (Foley et al., 2005) and climate (Malhi et al., 2008 and Nobre, 2014, p. 42) services, such insights may be of great relevance, since the demographic growth during the last decades has been impressive: the overall population of the Legal Amazon rose from about 2.5 million in 1960 to over 24,3 million today, a 10 -fold increase (IBGE, 2010). In the same period, almost 71 million hectares were deforested, equivalent to $18 \%$ of the original forest cover, with important annual rates of deforestation, even if since 2009 the phenomenon has been lowered to about $5000 \mathrm{~km}^{2}$ per year (Le Tourneau, 2016, Nepstad et al., 2009 and Instituto Nacional de Pesquisas Espaciais (INPE), 2015). If a lot of studies have shown the influence of different factors on deforestation, like the presence of roads (Kirby et al., 2006; Laurance et al., 2002 and Perz et al., 2008) and land tenure issues (Araujo et al., 2009, Ostrom and Nagendra, 2006, Paneque-Gálvez et al., $\underline{2013}$ and de Espindola et al., 2012), few recent studies have addressed the relationships between population densities and deforestation in the Brazilian Amazon.

This paper investigates the mixed relationship between human population density and deforestation in the Amazon for the 2000 to 2010 period. Our research hypothesis is that there is a low overall relation in the Amazon for population and deforestation because local conditions vary widely. For example, strong deforestation rates may be observed in areas of low population densities because of expansion of large-scale agriculture and cattle ranching. This issue of the heterogeneity of population settlement patterns and their impacts on natural resources in the Amazon is critical for policy makers concerned with land-use planning.

First, we examine the partition of urban and rural population and its variations across the Amazon, identifying human settlement patterns (from dispersed rural population to dense 
city centers). Then, we investigate the transformations of such settlement patterns between 2000 and 2010 and analyze possible relationships between such transformations and the evolution of deforestation during the same period.

The basis of our analysis are the database on deforestation released by the Brazilian space research center (INPE) (INPE, 2015) and the population census data at the census sector level published by the federal geographical and statistical agency IBGE (IBGE, 2010). Using such fresh data at the sub-municipality scale, we aim at bringing an accurate vision of the human occupation of the Amazon both in the land use frontier and in its remotest parts.

\section{State of the art}

\subsection{Deforestation processes and human settlements in the Brazilian Amazon}

The large-scale colonization process of the Brazilian Amazon since the 1960s resulted in different human settlement patterns with different combinations of population density and deforestation.

\subsubsection{In-migration and Amazonian land use frontier consolidation}

In the 1960s and 1970s, the military government began to promote rural colonization of the Amazon in order to populate and to integrate it to the Brazilian economy. Several public policies were implemented to accelerate immigration and economic development in the region and have contributed to the appearance of large-scale deforestation (Fearnside, $\underline{2005}$ ). Construction of major transport infrastructures began and ambitious colonization programs (both private and state sponsored) tried to attract smallholders in the region under the motto "Lands without men for men without lands" (Le Tourneau \& Bursztyn, 2011). Hundreds of thousands of families arrived in the region and began to convert the forest into agricultural lands (Morton et al., 2006). In these areas of small-scale family farming, the underlying human settlement pattern tends to be a combination of medium to high population density and medium to high deforestation, except where land speculation takes place, giving way to the installation of latifundios.

In the 1970s and 1980s, generous fiscal incentives were also implemented in order to attract large firms into the Amazon, leading in a vast majority of cases to the establishment of largescale cattle ranching and to the conversion of forest areas to pasture (Carvalho et al., 2002). Last, several big infrastructure projects (Tucurui dam, Transamazônica highway, etc.) were also responsible for the migration of workers to the Amazon and the further installation of these in public lands and local towns (Browder \& Godfrey, 1997).

In the 1980s, forest conversion to pasture continued to expand because of land speculation: creating pasture in forest areas was a cheap way to create "productive land", to claim land titles and to sell the new properties with high profits in a context of rapid rise of land prices (Nepstad et al., 2006 and Nepstad et al., 2006). This system of extensive, low-input cattle ranching motivated by land speculation resulted in creating large areas of degraded land (Bowman et al., 2012 and Carvalho et al., 2002) with few human settlements. Indeed, large 
scale ranching has contributed to the evolution of the human settlement pattern with the emergence of large areas with relatively low population density and high deforestation.

\subsubsection{Deforestation driven by distal demand for agricultural products}

In the 1990s, soybean began to expand into the Amazon thanks to the development of new adapted technologies (Fearnside, 2001) and to the rise of soybean prices on the international market. With the growing international demand for soybean, large-scale mechanized agriculture expanded into the southern and eastern extent of the Brazilian Amazon and modified the rural dynamics of the region. The soybean industry expansion contributed to a new valorization of land, leading ranchers to sell their properties and seek new areas further north where land prices were lower, participating to the land use frontier advance (Nepstad et al., 2006 and Nepstad et al., 2006) and to a trend toward depopulation of the rural areas (Lapola et al., 2014). Thus large-scale crop production has added a new pressure on the forest due to direct deforestation for cropland implantation and to intensified use of lands previously cleared for cattle ranching (Arvor et al., 2012 and Morton et al., 2006). Thereby, the human settlement pattern consisting in low population density and high deforestation has been expanding through the Amazon frontier.

Moreover, as for the big infrastructure projects of the 1970s and 1980s, the magnitude of investments for the commodities production and exportation led to a rapid growth of the cities located along one of the Amazon's export corridors (Richards \& VanWey, 2015). This has contributed to the attraction of rural population and to the multiplication of quite densely populated urban areas.

\subsubsection{Toward the conciliation of forest conservation and human settlement: the progressive recognition of the land rights of Amazonian "traditional" peoples}

In parallel, since the 1990s, the "traditional" peoples of the Amazon, including Indigenous peoples, but also Quilombolas communities (communities formed by descendant of fugitive slaves) and other communities whose subsistence historically depends of non-timber forest products (ex. Rubber-tappers) have gained collective land rights on relative large portion of their ancestral territories. Today, about $21.7 \%$ of the Brazilian Amazon is classified as Indigenous land and $14.5 \%$ is under diverse protected areas aiming at conciliating the presence of rural communities and the conservation of the Amazon forest ( Veríssimo, Rolla, Vedoveto, Futada, \& de, 2011, p. 87). In these areas of forest extractivism and slash and burn agriculture, the underlying human settlement pattern is a combination of low to medium population density and low deforestation.

Adding to this, $8.9 \%$ of the Amazon is under integral protected areas where human presence is forbidden (therefore theoretically registering zero population and zero deforestation).

As this quick historical description shows, the Amazon consists in a vast mosaic of diverse land tenures and human settlement pattern, both terms having influenced each other (Nasuti, Tritsch, \& Eloy, 2015).

\subsubsection{New trends of Amazonian deforestation}


Since 2009, the efforts of the Brazilian government to curb deforestation induced a spectacular diminution on the annual deforestation rates and the progressive decoupling of agricultural expansion and deforestation (Gollnow and Lakes, 2014, Le Tourneau, 2016, Macedo et al., 2012 and Nepstad et al., 2009), suggesting that it is possible to manage the advance of the Amazon frontier (Nepstad et al., 2014). A number of recent studies have addressed the question of the current diminution of deforestation. These studies underlined the role of ambitious and effective command-and-control environmental public policies (such as the Action Plan for Prevention and Control of Deforestation in the Amazon, PPCDAm) (Nepstad et al., 2014), increased market regulations such as the Soy and Beef Moratorium (Gibbs et al., 2015, Rudorff et al., 2011 and Soares-Filho et al., 2014), economic incentives such as payments for environmental services (Börner, Marinho, \& Wunder, 2015), but also agricultural intensification process (Arvor et al., 2012 and Morton et al., 2006). Concerning the responsibility of different social actors on deforestation, Godar, Gardner, Tizado, and Pacheco (2014) showed that during the 2004-2011 period, the contribution of the largest landholders to annual deforestation decreased over time whereas that of smallholders went up by a similar amount, particularly because command and control policies have focused on larger properties in deforestation hotspots.

However, Lapola et al. (2014) stress that these news trends in the Amazon land use induce a commoditization of the land and tend to reinforce the long history of inequality in land ownership. This contributes to the rise of rural-urban migrations and thus to the transformation of the human settlement dynamics (Richards \& VanWey, 2015).

\subsection{Human settlement pattern theory of the land use frontier}

The deforestation processes and human settlements pattern in the Brazilian Amazon are consistent with the theories of frontier cycle and land use transition (DeFries et al., 2004 and Foley et al., 2005). The frontier can be conceptualized as a moving fringe separating forested areas from areas where population settlements and human activities are consolidated (Arvor et al., 2012). At the beginning of the cycle, increased population density from in-migration tends to induce forest conversion and farmland expansion in a process of extensification. As the frontier evolves, population density increases both from in-migration and fertility and can lead to some agricultural intensification in order to take advantage of the labor force and because of waning forest resources. Then, land consolidation usually induces a rise of the price of land which encourages small farmers to sell their properties to bigger ones, leading to lower population densities because of the expansion of large landholdings (latifundio). This frontier dynamic is known as the "hollow" frontier (Rudel et al., 2002 and Walker, 2004). Consequently, the less capitalized smallholders either move forward to other frontier areas or migrate to urban areas where they hope to find better living standards, thus contributing to the urban population growth (Browder and Godfrey, 1997 and Perz et al., 2005). In both case, despite the decline of rural population, deforestation tends to persist since the lands sold by the smallholders are converted by big farmers for commodity crops or pastures ( Carr, 2004 and Fearnside, 2008). Thus, these theories suggest that the demographic aspects of the tropical deforestation are dynamic and time-dependent in relation with the stage of the land use frontier. These different population-deforestation patterns can be viewed as situated at different points along a curve that describes the process of frontier settlement. 


\section{Materials and methods}

\subsection{Demographic data}

Brazil publishes high-precision data on its population and socio-economic conditions through the decennial population census (IBGE, 2010). The census data are public and freely available on the IBGE site, in the form of aggregated indices at the municipality scale and, since the 2000 census, in the form of an extensive list of variables at the census sectors scale, for which geo-referenced shapefiles are also available. The census sector level presents a spatial scale 48 times more spatially refined than the municipality level which is generally used in studies looking at demographic and socio-economic factors for the Brazilian Amazon. In fact, IBGE raw data are produced for 37,295 census sectors covering the entire Amazon while there are only 775 Amazonian municipalities. It must be noted however that the IBGE census sectors have changed between the 2000 and 2010 censuses, which makes comparisons between the two periods problematic, unless the data are projected in a uniform grid.

\subsection{Deforestation data}

Brazil has extensive data on the Amazon forest area cleared annually through its PRODES program of the INPE, based on the remote sensing analysis of images of multiple satellites (LANDSAT, CBERS, UK2-DMC, RESOURCESAT) (INPE, 2013). The PRODES is the world's most complete and enduring tropical forest monitoring program, offering exhaustive data used by several studies analyzing the Amazon deforestation dynamics (Börner et al., 2015 and Nolte et al., 2013). The minimum deforested area mapped by the PRODES is 6.25 ha, and deforestation is defined as the complete removal of forest cover thus not including forest degradation. Reforestation and forest regrowth processes are not considered either: a polygon deforested at year $\mathrm{N}$ will always continue classified as 'deforested'. Finally, the PRODES only considers areas originally covered by forest vegetation (ie. areas forested in the pre-1970s). So there is no deforestation data available for all the savannas (Cerrado) included in the Brazilian Legal Amazon (near 1 million square kilometers south but also in Roraima and Amapá, in the northern part of the region). For this reason, our analysis does not consider the areas covered by non-forest vegetation (Cerrado).

\subsection{GIS data processing}

In order to link the deforestation data and the demographic data from the census sectors of 2000 and 2010, using a GIS, all the data were projected in quadrats of $10 \times 10 \mathrm{~km}$, covering the whole Brazilian Legal Amazon (5,000,000 square kilometers). Although the PRODES deforestation data would allow for a finer resolution, $10 \times 10 \mathrm{~km}$ was judged suitable because of the large size of most rural census sectors. For each quadrat, deforestation and demographic variables were calculated for the year 2000 and 2010. Four steps were performed to accurately project the PRODES and the census sectors data into the $10 \times 10 \mathrm{~km}$ grid: 1) calculation of the surface of original forest for each quadrat by subtracting nonforest areas and waterways, 2) calculation of the quantity of deforestation for each quadrat, 3 ) calculation of the estimated density of demographic variables according to the surface of the IBGE census sectors, 4) calculation of the absolute values of demographic variables for each quadrat (Fig. 1). 
Use of $\mathbf{4}$ different georeferenced shapes:

a) Census setors (IBGE)

1000 inhabs

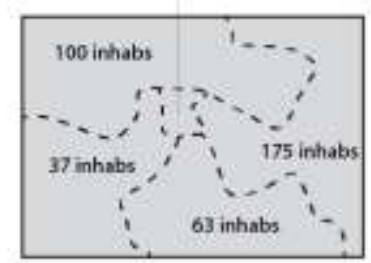

b) Map of deforestation (PRODES)

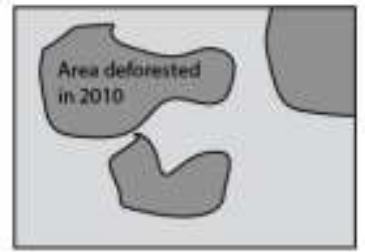

c) Geographical objects (non-forest areas, roads, etc.)

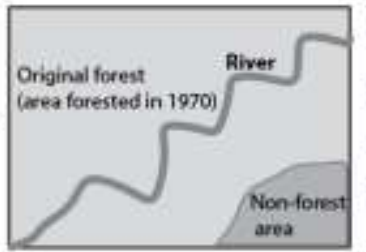

d) Grid of $10 \times 10 \mathrm{~km}$ quadrats

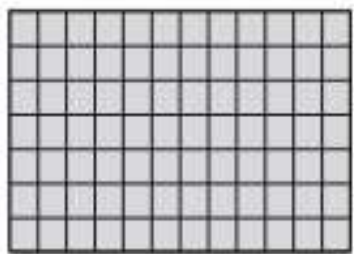

Step 1: Calculation of the surface of original forest for each quadrat

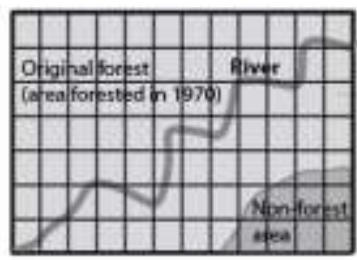

Quadrat $Y=100 \mathrm{~km}^{2}$ in original forest fie. $100+$ of the quadrat's area)

Quadrat $Z=65 \mathrm{~km}^{2}$ in original forest

Step 2: Calculation of the quantity of deforestation for each quadrat until 2000 and until 2010

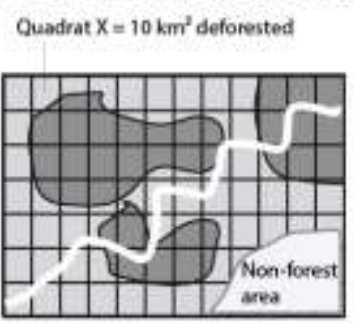

Step 3: Calculation of the estimated density of demographic variables in 2000 and 2010 according to the surface of the IBGE census sectors

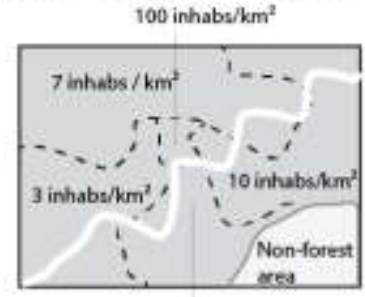

4 inhabs $/ \mathrm{km}^{2}$

Step 4: Calculation of the absolute values of demographic variables for each quadrat

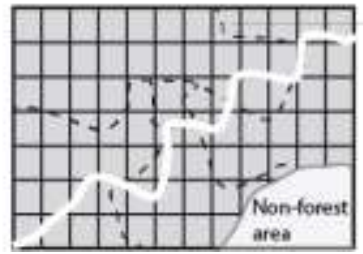

Quadrat $Y=60 \mathrm{~km}^{2}$ with 10 inhabs $/ \mathrm{km}^{1}$ and $40 \mathrm{~km}^{2}$ with 7 inhabs $/ \mathrm{km}^{2}$

$\Rightarrow 880$ inhabitants

Fig. 1. GIS processing of the data: projection of PRODES and IBGE census sectors data into a $10 \times 10$ regular grid. 
Step 1 Calculation of the surface of original forest for each quadrat by subtracting non-forest areas and waterways.

The surface originally covered by forest vegetation was calculated for each quadrat. It refers for the INPE to the areas covered by forest in the early 1970, and can be obtained on GIS by subtracting the areas that are not covered by water bodies and by savannas and other nonforest vegetation according to the INPE shapes. This surface in original forest is our reference surface for the study and will be used to calculate the quadrats' total deforestation in 2000 and 2010. In order to do not distort our interpretations of the dynamics of deforestation, we excluded from our analysis all quadrats situated along the margins of the Legal Amazon and those that had less than $70 \%$ of their surface covered by original forest.

We therefore consider in our analysis an Amazonian area of 4 million square kilometers, inhabited by 18.4 million people in 2010, representing 40,408 quadrats in our database.

Step 2 Calculation of the quantity of deforestation for each quadrat.

In the step 2, all the deforestation polygons were intersected with the $10 \times 10 \mathrm{~km}$ grid. At that point, the surface of all the fragments of deforestation polygons included in each quadrat was summed and the total deforestation of each quadrat was calculated in function of the surface in original forest obtained in step 1.

Step 3 Calculation of the estimated density of demographic variables according to the surface of the IBGE census sectors.

Demographic and socio-economic data released by the IBGE use individuals or households as units. We converted them in densities by dividing them by each sector's size in $\mathrm{km}^{2}$. By doing so, we presumed that population density within a sector is equal throughout the sector, which is a necessary assumption in any population density study. This assumption is obviously much more valid for small urban sectors than for big rural ones. However, as the data used are the most detailed data available, we think that apart from some misrepresentations in extreme cases, it is statistically sound.

Step 4 Calculation of the absolute values of demographic variables for each quadrat.

Once the demographic and socio-economic variables expressed as estimated density, census sectors were intersected by the grid of $10 \times 10 \mathrm{~km}$ quadrats. For each fragment of census sectors, the absolute values of these variables were calculated according to the area of the fragment. Then the absolute values of all the fragments included in the same quadrat were summed, allowing the calculation of the demographic and socio-economic data in 2000 and 2010 for each quadrat.

These data were associated to the deforestation data in a database composed of 40,408 quadrats with the following variables:

- Demographic indicators in 2000 and 2010: the estimated number of inhabitants and the population density, 
- Total deforestation (see definition in Section 3.2) in 2000 and 2010: the total area deforested registered by PRODES for year 2000 (i.e. summing up the deforestation between the 1970s and 2000) and for year 2010 (i.e. summing up the deforestation between 1970s and 2010).

- Territorial indicators on land tenure (type of protected areas) and distance to the major roads, to major navigable rivers and to state capitals, calculated from GIS data of the Brazilian minister of environment (http://mapas.mma.gov.br/i3geo/datadownload.htm).

Data processing was carried using a GIS developed on the free software QGIS 2.6.1 and GRASS GIS 6.4.3.

\subsection{Data analysis}

\subsubsection{Classification of quadrats according to their human settlement patterns}

The 40,408 quadrats were classified into ten human settlement patterns ( $\mathrm{A}$ to $\mathrm{J}$ ) according to the thresholds of deforestation extent and population density presented in Fig. 2.

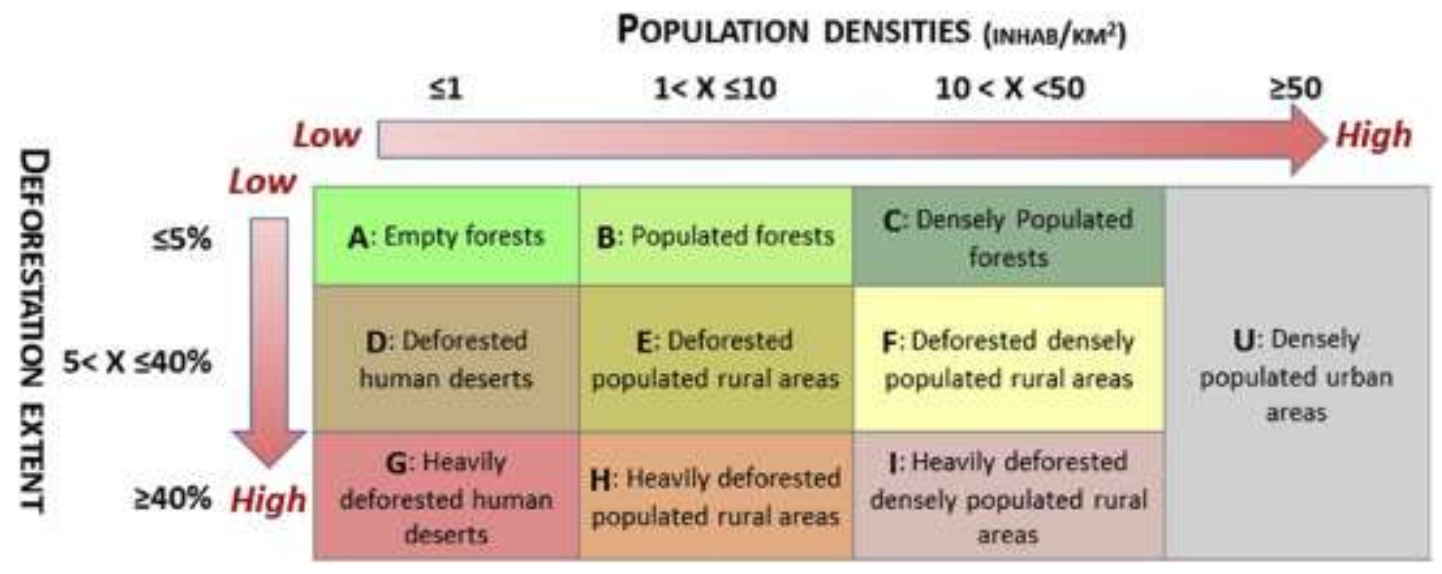

Fig. 2. Definition of human settlement pattern classes (A to J) according to population density in 2010 and deforestation extent in 2010.

The rationale for defining these classes of human settlement patterns was first of all based on the level of population density. Hence, all quadrats with less than 1 inhabitant per square kilometer in the period analyzed were considered as "desert", those with 1-10 were considered as "populated", those with 10-50 as "densely populated" and those with more than 50 inhabitant per square kilometer (i.e. sheltering more than 5000 persons) were considered as very densely populated "urban". Deforestation extent in 2010 was then used to situate quadrats in relation to the land use frontier, with those with low deforestation extent (less than 5\%) considered "forested", those with deforestation extent 5-40\% considered "deforested" and those with more than $40 \%$ deforestation extent considered "heavily deforested". The thresholds applied were defined attempting to capture the variability in the population and deforestation variables.

\subsubsection{Statistical analysis}


Statistical analyses were performed on the R statistical free software, version 3.1.0 (

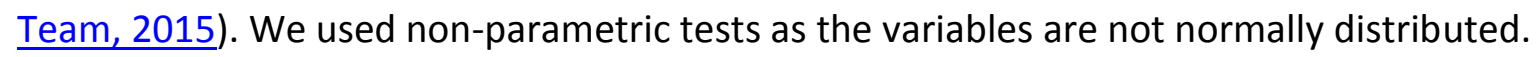
We evaluated the statistical relationships among the classes of human settlement patterns and the demographic and territorial variables using the Kruskal-Wallis test and the Tuckey's honestly significant different test.

\section{Results: characterization of the human settlement patterns in the Brazilian Amazon}

Our results show very distinct patterns of human settlement with low-low and high-high classes of population density and deforestation, and also low-high and high-low classes as illustrated in Fig. 3 and Table 1 . There is a low overall relation in the Amazon for population and deforestation with four main contrasted patterns that we detail bellow.

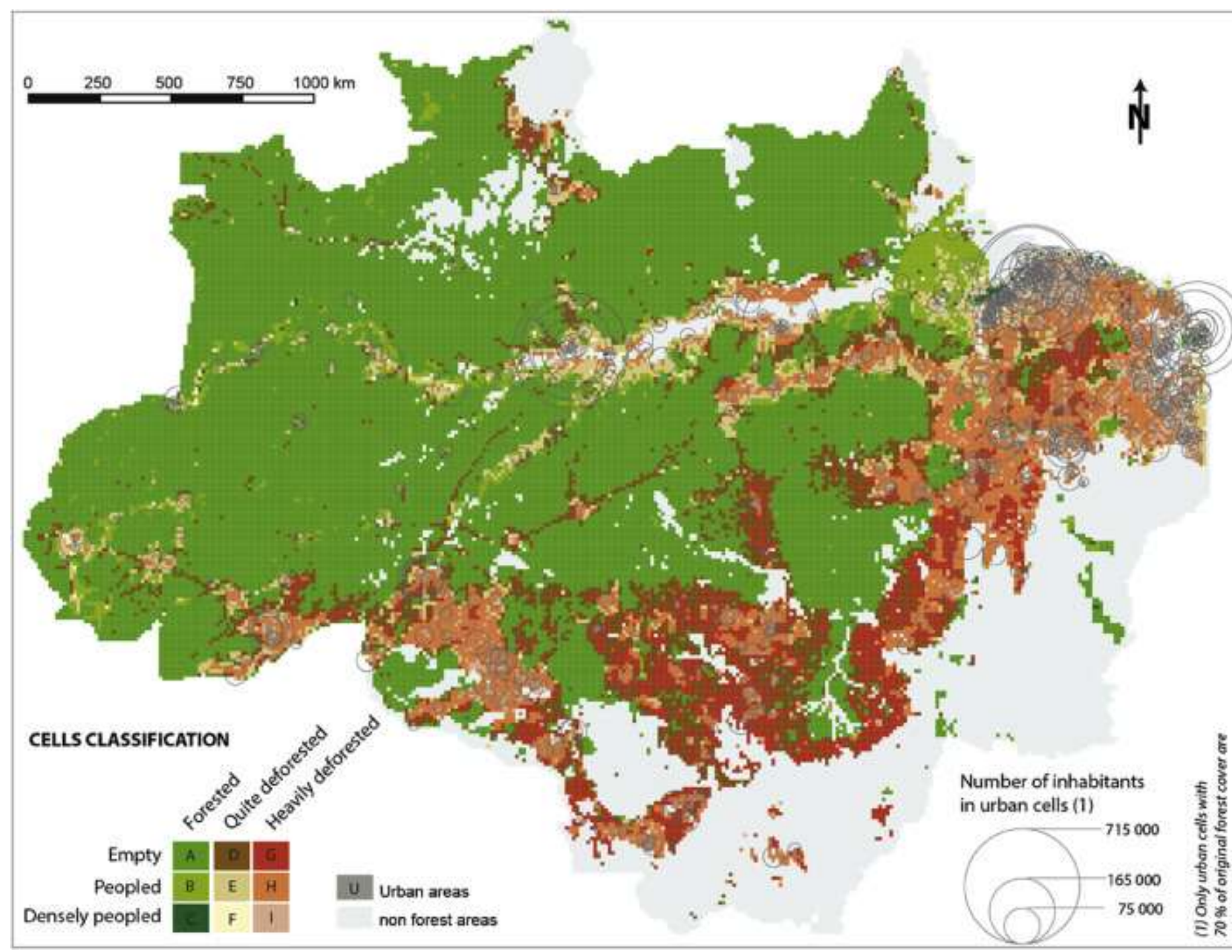

Fig. 3. Human settlement patterns in the Brazilian Amazon in 2010.

Table 1. Comparison of selected variables of each human settlement pattern. 


\begin{tabular}{|c|c|c|c|c|c|c|c|c|c|c|}
\hline $\begin{array}{c}\text { Human } \\
\text { settlement } \\
\text { pattern }\end{array}$ & $\begin{array}{l}\text { Nb. of } \\
\text { cells } \\
\text { in } \\
2000\end{array}$ & $\begin{array}{l}\text { Nb. Of } \\
\text { cells } \\
\text { in } \\
2010\end{array}$ & $\begin{array}{l}\text { Inhabitants } \\
\text { in } 2000\end{array}$ & $\begin{array}{l}\text { Inhabitants } \\
\text { in } 2010\end{array}$ & $\begin{array}{l}\text { Population } \\
\text { variation } \\
(2000- \\
2010)(\%)\end{array}$ & $\begin{array}{l}\text { Percent of } \\
\text { the } 2010 \\
\text { whole } \\
\text { population } \\
\text { (\%) }\end{array}$ & $\begin{array}{c}\text { Total } \\
\text { deforestation } \\
\text { in } 2000\left(\mathrm{~km}^{2}\right)\end{array}$ & $\begin{array}{c}\text { Total } \\
\text { deforestation } \\
\text { in } 2010\left(\mathrm{~km}^{2}\right)\end{array}$ & $\begin{array}{l}\text { Percent of } \\
\text { the } 2010 \\
\text { total } \\
\text { deforestation } \\
\text { (\%) }\end{array}$ & $\begin{array}{c}\text { Mean } \\
\text { distance } \\
\text { from } \\
\text { major } \\
\text { roads } \\
(\mathrm{km})\end{array}$ \\
\hline $\begin{array}{l}\text { U: densely } \\
\text { populated urban } \\
\text { areas }\end{array}$ & 442 & 526 & $10,081,791$ & $13,134,369$ & 30.28 & 71.55 & 30,196 & 33,603 & 4.85 & $\mathrm{NA}^{*}$ \\
\hline A: Empty forests & 26,636 & 24,623 & 419,533 & 302,272 & -27.95 & 1.65 & 4646 & 8158 & 1.18 & 117.60 \\
\hline $\begin{array}{l}\text { B: Populated } \\
\text { forests }\end{array}$ & 2013 & 1467 & 251,148 & 309,502 & 23.23 & 1.69 & 864 & 1759 & 0.25 & 99.96 \\
\hline $\begin{array}{l}\text { C: Densely } \\
\text { Populated } \\
\text { forests }\end{array}$ & 119 & 58 & 52,598 & 76,606 & 45.64 & 0.42 & 77 & 55 & 0.01 & 47.80 \\
\hline $\begin{array}{l}\text { D: Deforested } \\
\text { human deserts }\end{array}$ & 3492 & 3871 & 159,466 & 125,780 & -21.12 & 0.69 & 31,726 & 68,782 & 9.93 & 42.25 \\
\hline $\begin{array}{l}\text { E: Deforested } \\
\text { populated rural } \\
\text { areas }\end{array}$ & 1974 & 1907 & 449,605 & 515,376 & 14.63 & 2.81 & 21,201 & 37,144 & 5.36 & 45.35 \\
\hline $\begin{array}{l}\text { F: Deforested } \\
\text { densely } \\
\text { populated rural } \\
\text { areas }\end{array}$ & 202 & 193 & 323,664 & 335,235 & 3.58 & 1.83 & 2549 & 3576 & 0.52 & 33.56 \\
\hline $\begin{array}{l}\text { G: Heavily } \\
\text { deforested } \\
\text { human deserts }\end{array}$ & 1415 & 2554 & 151,856 & 115,316 & -24.06 & 0.63 & 117,070 & 162,171 & 23.41 & 17.92 \\
\hline $\begin{array}{l}\text { H: Heavily } \\
\text { deforested } \\
\text { populated rural } \\
\text { areas }\end{array}$ & 3192 & 4211 & $1,556,802$ & $1,422,535$ & -8.62 & 7.75 & 238,847 & 300,301 & 43.36 & 13.52 \\
\hline $\begin{array}{l}\text { I: Heavily } \\
\text { deforested } \\
\text { densely } \\
\text { populated rural } \\
\text { areas }\end{array}$ & 923 & 998 & $1,736,042$ & $2,020,439$ & 16.38 & 11.01 & 68,336 & 77,098 & 11.13 & 7.25 \\
\hline TOTAL & 40,408 & 40,408 & $15,182,505$ & $18,357,430$ & - & 100.00 & 410,149 & 692,647 & 100.00 & - \\
\hline
\end{tabular}

Note: All variables present significant variation across the human settlement pattern classes (Kruskal-Wallis: $p<0.0001$ ). * Not Applicable because the roads network considered does not take into account the urban and municipality roads.

\subsection{Densely populated urban areas are increasing (pattern U)}

A large proportion of the Amazonian population is concentrated in towns or cities: $71.5 \%$ of the population (13.1 million people) live in urban areas in 2010 (quadrats with a population density greater than 50 inhabitants/km2, pattern $U$, Table 1). They are spread over 526 quadrats in 2010 , corresponding to less than $1.2 \%$ of the overall original forest area of the Amazon (46,082 km2).

This urban population has increased by $30.3 \%$ in 10 years, meaning an increase of more than 3 million inhabitants between 2000 and 2010. In 2000, there was only 442 densely populated urban quadrats against 526 in 2010 (19\% increase) and the proportion of urban population was 'only' $66.4 \%$. This trend of increasing urbanization is sustained by a strong rural exodus: if the urban population show a $30.3 \%$ increase in 10 years, the whole rural population only grew from $2.4 \%$ in the same period (passing from 5,100,714 to 5,223,061 inhabitants). Cities attract people because they offer better access to jobs and public 
services such as school and healthcare (Nasuti et al., 2015 and Tritsch et al., 2015). Moreover, rapid midsize cities growth is closely tied with traded commodities production because these cities capture capital and value before it is extracted from the region (Richards \& VanWey, 2015).

\subsection{Preserved forests have different human settlement patterns: from "empty" forests to populated forests (patterns A to C)}

In areas where forest cover is well preserved (quadrats with less than $5 \%$ deforestation in 2010), contrasted situations are observed. On the one hand, the "empty" forests cover a large surface: $61.6 \%(2,405,551 \mathrm{~km} 2)$ of the Amazon forest have less than 1 inhabitants $/ \mathrm{km} 2$ $\left(24,623\right.$ quadrats) (Table 1) and $42.1 \%\left(1,642,725 \mathrm{~km}^{2}\right)$ have a population density inferior to $0.1 / \mathrm{km}^{2}$. Not surprisingly, such areas are often located far from roads and main waterways (Table 1, Fig. 3). Their average population density is only 0.13 people $/ \mathrm{km} 2$. On the other hand, the number of people living in those well preserved forest is not as low as one can imagine. A total of 688,380 people (13\% of the rural population) live in areas where deforestation is less than $5 \%$ (patterns A, B and C), showing that an important fraction of the Amazonian rural population still has a way of life consistent with the maintenance of forest cover. Moreover, the numbers of inhabitants of the "populated forests" (pattern B) and "densely populated forests" (pattern C) have augmented between 2000 and 2010, with respectively a $23 \%$ and $46 \%$ increase.

\subsection{Low population densities and deforested areas: the increase of "deforested human deserts" (pattern D and G)}

In contrast, some heavily deforested areas have very low population densities: 2554 quadrats have more than $40 \%$ of their area deforested in 2010 but have population densities lower than 1 inhabitants/km2 (pattern G). They represent a deforested area of 162,171 km², accounting for $13 \%$ of the 2010 whole deforestation, for only $0.6 \%$ of the Amazonian population (115,316 inhabitants) (Table 1). These "heavily deforested human deserts" areas are situated next to the main roads, in average $18 \mathrm{~km}$ (median $=10 \mathrm{~km}$ ) and mainly in the south and southeast of the Amazon (Table 1, Fig. 3).

The tendency of heavily deforested areas to have low population densities seems to be accelerating in the Amazon: in 2000, the pattern G had only 1415 quadrats against 2554 in 2010, which represents an increase of $80.5 \%$ in ten years (Table 1). Moreover, the pattern D (deforestation extent between 5 and $40 \%$ and population densities smaller than 1 inhabitants $/ \mathrm{km} 2$ ) already counts 3871 quadrats in 2010 (Table 1). If the deforestation in such areas persists, these quadrats will certainly turn into "heavily deforested human deserts" (pattern G) and so will contribute to the expansion of the pattern consisting of low population densities living in heavily deforested areas.

Moreover, settlement patterns $D$ and $G$ have registered a decrease in their total population between 2000 and 2010, while during the same period their total deforested area has been rising. The population of pattern $\mathrm{G}$ decreased by $24 \%$ between 2000 and 2010 though, over the same period, deforestation has risen by $38.5 \%$. For the pattern $D$, population decreased from $21 \%$ in ten years while deforestation has risen by $117 \%$ in the same period. 


\subsection{High number of inhabitants in heavily deforested rural areas: patterns $E, F$, $\mathrm{H}$ and $\mathrm{I}$}

On the other hand, some deforested rural areas are heavily populated (at least according to Amazonian standards). In 2010, the pattern I (population densities from 10 to 50 inhabitants/ $\mathrm{km} 2$ and deforestation higher than 40\%) represented only 998 quadrats but sheltered 2.0 million inhabitants. The pattern $\mathrm{H}$, which has population densities from 1 to 10 inhabitants/ $\mathrm{km} 2$ and deforestation higher than 40\%, represented 4211 quadrats for 1.4 million inhabitants. Concerning patterns $E$ and $F$, they together represent 2100 quadrats for 850,611 inhabitants (Table 1).

\section{Discussion: main dynamics of human settlement in the Brazilian Amazon}

\subsection{Trends towards rural population concentration in growing villages or small towns and 'discrete urbanization'}

In rural areas of the Amazon, our analysis shows a trend toward rural population concentration in more densely populated rural areas and, correlatively, a trend toward depopulation of the other ones. Rural quadrats with 10-50 inhabitants/km2 are experiencing a 15\% increase in their population (going from 2.1 to 2.4 million inhabitants between 2000 and 2010) whereas quadrats with less than 10 inhabitants $/ \mathrm{km} 2$ face a $6.6 \%$ decrease in their population.

This concentration of rural population in some big growing villages reflects the trend toward rural Amazon 'villagization', defined by Eloy, Brondizio, and Do Pateo (2015) as a process of demographic growth and spatial expansion of the main rural villages. This 'discrete urbanization' of the Amazon occurred especially in downstream areas near state capitals and roads and around the secondary education poles (Costa and Brondízio, 2011 and Parry et al., 2010). On the one hand, in remote areas, the displacement of people toward more densely populated areas may reflect the lack of infrastructures and the importance of transportation costs (especially on rivers) (Parry et al., 2010 and Tenkanen et al., 2015). Nowadays, most families feel the need to go to town at least one time a month in order to receive social benefits from cash transfer programs (ex. Bolsa familia and rural retirement), or even more frequently in case there are youngster studying at the college ( Eloy et al., 2015 and Nasuti et al., 2015). On the other hand, in rural areas situated close to the main road network, the improved access to road facilities has simplified the rural mobility (Théry, 2014).

Such shifts greatly change the profile of the Amazon region, currently mainly viewed by public policies as a rural region with only two big metropoles, Belém and Manaus. The multiplication of small towns and second-order cities modifies the needs and should provoke a major overhaul in policies in order to respond to them. For instance, water treatment and waste collection are failing in most Amazonian cities, turning them into emitters of different types of pollution which, in turn, will threat the environment of vast regions surrounding them. 
Finally, the shortening of fallow lengths around these growing villages, due to higher population densities and scarcity of available land, challenges the land use sustainability in these areas since agricultural systems are still mainly based on extensive slash and burn agriculture. The question of subsistence hunting in these rural areas of higher population densities is also complicated (Tritsch, Gond, Oszwald, Davy, \& Grenand, 2012). In consequence, more and more households stop their subsistence agricultural activity and local food (ex. Cassava) tends to be substituted by imported food (congealed chicken and food made from wheat), threatening local food independence (Peralta \& Kainer, 2008). On the other hand, cash transfer programs and local jobs available in these growing villages and small towns enable households to buy imported food, which help stabilize forest frontiers because households become less reliant on subsistence agricultural production (van Vliet, Adams, Vieira, \& Mertz, 2013). For all these reasons, agro-ecological programs promoting alternative ways of sustainable production, such as agroforestry systems, must be implemented in order to support farmers in the adaptation of their production systems to these news social and environmental conditions.

\section{2. "High deforestation - low population": expansion of large-scale agriculture and depopulation of deforested rural areas}

We showed that high deforestation may be observed in areas of low population densities: almost one third of the Amazonian deforestation in 2010 is associated with less than $1.5 \%$ of the Amazonian population, representing what we have called "deforested human deserts" (pattern $G$ and D). The population density of these areas declined between 2000 and 2010 while the deforestation increased, indicating that the amount of deforestation on a perinhabitant basis increased. Thus, these areas present a trend toward rural depopulation and a demographically "hollow" frontier. This suggests that smallholders are selling their land to cattle ranchers and large scale farmers. As emphasized by Fearnside (2008) and López-Carr and Burgdorfer (2013), in these deforested areas of low population density, large-scale farmers and cattle ranchers are most likely responsible for deforestation.

The increase in the extent of these areas (pattern G and D) between 2000 and 2010 shows that deforestation does not necessarily go along with settlement of fixed population. The activities implemented in the arc of deforestation have failed in fixing human settlements, at least in recent times, despite the common discourse on the Amazon linking deforestation to local demographic expansion (Kirby et al., 2006; Laurance et al., 2002). In fact, the Amazonian land use frontier has always been multifaceted, mixing small-scale colonization and large-scale latifundios. However, today, the relative weight of each term may have shifted. The process of agrarian colonization, as idealized in the years 1970 and pursued until the late 1990s, which aimed to settle rural families, has largely stepped back today, except for a few regions. At the same time, a complex process of large-scale mechanized agriculture and cattle ranching implementation has occupied a growing proportion of the Amazon. Such large estates employ and harbor small numbers of people in favor of an even smaller number of landowners, a characteristic situation of the concentration of large tracts of land in some few hands ( Pacheco et al., 2011).

The per capita environmental cost of such latifundio areas is obviously very high, but is offset in public discourse by the economic return of commodities exports. However, there is a 
growing pressure toward diversification of production, and toward intensification and value aggregation of the agricultural production (turning, for instance, from soybean to hog and chicken meat production). But the fitness of the current demographic profile for such purpose is not guaranteed.

Public policies could thus take advantage of the precise mapping which may be realized by studies such as ours in order to promote focused land-reform policies and generally increase demographic densities in the already deforested areas, thus alleviating part of the pressure felt in other areas. In this sense, the restoration of degraded areas should be prioritized. Indeed, Martini, Moreira, Formaggio, and Dalla-Nora (2015) recently mapped an amount of $200,000 \mathrm{~km}^{2}$ of already converted areas in the Brazilian Amazon which could support human settlement and agricultural expansion without promoting the advance of deforestation. Efforts such as the recent agriculture program ABC (Plano para uma Agricultura de Baixo Carbono) which aims to ensure a transition toward a more environmental friendly agricultural model, for example by promoting the restoration of degraded pastures, should be pursued.

\section{3. "Low deforestation - high population": role of land tenure and public policies to encourage forest conservation and human settlement}

According to our data, 688,380 people (around $13 \%$ of the Amazon rural population) lives in forest without causing massive deforestation. The inhabitants of these "preserved" forests (deforestation $<5 \%$ ) show that, even today, human presence may be associated with forest conservation. Indigenous peoples are part of those 600,000 people who live in the forest without cutting it down. However, they are not the only ones, because the indigenous people living inside indigenous territories do not represent more than 250,000 people in the Brazilian Amazon, or about $42 \%$ of those inhabitants.

Much of these "preserved" forest areas are characterized by specific forms of land tenure: $69.2 \%$ are located in indigenous lands or different types of protected areas. This reinforces the idea that the recognition of specific land tenure types such as indigenous lands and protected areas participate in curbing deforestation, especially in areas of high pressure on natural resources (Nolte et al., 2013 and Pfaff et al., 2015), the former probably being the most efficient (Nepstad et al., 2006 and Nepstad et al., 2006). It also means that $30.8 \%$ of these preserved forests (representing $783,280 \mathrm{~km} 2$ ) are not registered under any special land tenure and so have an uncertain future concerning their future land use.

The presence of population in the Amazon necessarily implies a certain proportion of deforestation to practice small scale agriculture. But deforestation remains low in these "preserved" forests: on average only $0.18 \%$ of the overall forest cover of the quadrats were removed between 2000 and 2010 (9992 km2 deforested in 2010). However, if these areas present a low amount of forest clearing on a per-inhabitant basis and are good examples of how to combine the maintain of rural population and the conservation of forest cover, it is important to emphasize that they are vulnerable nowadays because of the falling prices of many non-timber forest products, which result in a decline of traditional economic activities. In this context, the attractiveness of the more environmentally destructive economic activities (like cattle ranching) increases due to a lack of other options (Schwartzman \& 
Zimmerman, 2005). Therefore, there is currently an important issue about local economic opportunities for the younger generations. Indigenous territories constitute another important example about the tensions between conservation and development (Le Tourneau, 2015).

Hence, while this "low deforestation - high population" pattern is undeniably environmentally and theoretically important, its social and economic challenges remain significant as they complicate the picture of the Amazonian sustainability. This highlights the need for appropriate public policies and economic incentives, such as Payments for ecosystem services (PES), to support these rural populations ( Börner et al., $\underline{2015}$ and Pacheco et al., 2011). Different PES initiatives have already been implemented in the Brazilian Amazon, for example the Bolsa Floresta program, which encompasses a set of integrated interventions aiming at conserving forests and improving the welfare of residents in selected human-occupied protected areas of sustainable development or the REDD + pilot program PAS (Projeto Assentamentos Sustentaveis na Amazonia) in the Trans-Amazonian Highway. However, it still lacks evaluations of the impacts of these PES initiatives which are necessary to improve the sustainability of these programs and promote their wider implementation. So more studies like Simonet, Subervie, Ezzine-de-Blas, Cromberg, and Duchelle (2015) on the cost-effectiveness and additional and leakage effects of these initiatives should be encouraged.

\section{Conclusion}

As the Brazilian Amazon remains a moving frontier, the interactions between demography and deforestation are complex and changing. Since the launch of large scale development projects in the 1970s they have shaped different human settlement patterns which cannot anymore be treated by homogeneous public policies for the whole 'Legal Amazon'.

Two patterns are especially interesting. In one hand, in 2010, the "deforested human deserts" pattern accounted for almost one third of the total deforestation, highlighting that the Amazon deforestation cannot be viewed as a result of a demographic pressure. On the other hand, other regions have relatively important population densities and little deforestation, like in the "populated forest" pattern. These latter areas represent a series of experiments combining human presence and conservation of biodiversity and forest cover, which should be preserved by the implementation of supportive public policies.

However, the recent context of political and economic crisis could weaken the institutional capacity of the Brazilian government to ensure continuity with the ambitious and effective environmental and socio-economic policies that have significantly reduce the Amazon deforestation (Rodrigues-Filho, Verburg, Bursztyn, Lindoso, Debortoli, \& Vilhena, 2015) while enabling several millions of Brazilian to leave poverty behind (ex. Bolsa Familia, Fome zero, Luz para todos, and rural retirement programs) ( Barrientos, 2013 and Fenwick, 2013). In the Amazonian "populated forests", part of the current rural economy does rely on these social benefits ( Nasuti et al., 2015 and Tritsch et al., 2015). So, changes in the economic priorities of the Brazilian government can foster new transformations in the Amazonian human and land use settlement patterns. 
Our data also confirm the rapid growth of urban areas as shown by Richards and VanWey (2015). An important process of 'discrete urbanization' of the Brazilian Amazon must also be underlined: the rural population tends to concentrate in big growing villages or small towns with, correlatively, a trend towards depopulation of remote areas. A number of medium to big rural nuclei now constitute the backbone of the rural world in the Amazon, even in riverine areas. Thus, the problems associated with urban areas, in particular urban planning and waste treatment should gain more attention in the definition of public policies for the Amazon, as urban populations now encompass the majority of the Amazonian population. In the same way, the problems related with depopulation of rural landscapes such as increased fire activity (Uriarte et al., 2012) should also seriously be taken into account, especially as the projection of the United Nations predicts a major decline in rural population for Brazil until 2050 (United Nations, 2015).

The crossing of deforestation and demographic spatial data was useful in order to pinpoint the existence of different patterns and to quantify their extent. Our analysis of the relationship of population and deforestation in the Brazilian Amazon reveals a set of distinct combinations across the basin. Those combinations in turn require distinct policies to be effective in conserving forest where it still stands, taking into account varying population densities. The macro-zoning policy developed by the Brazilian Federal Government for the Amazon is a step toward recognizing the specificity of such regions, but the different regions are not detailed enough and the way it will be put concretely into effect is not clear at this stage.

\section{Acknowledgments}

We thank the University Sorbonne Nouvelle, Paris 3 and the CNRS - UMR CREDA for their funding sources. We are also grateful to the two anonymous reviewers for their constructive comments, which helped to improve the manuscript. The authors declare no competing interests. 